\title{
Pan-FGFR Tyrosine Kinase Inhibitor BAY1163877
}

National Cancer Institute

\section{Source}

National Cancer Institute. Pan-FGFR Tyrosine Kinase Inhibitor BAY1163877. NCI

Thesaurus. Code C112205.

A pan inhibitor of human fibroblast growth factor receptors (FGFRs) with potential antiang iog enic and antineoplastic activities. Pan-FGFR kinase inhibitor BAY1163877 inhibits the activities of FGFRs, which may result in the inhibition of both tumor angiogenesis and tumor cell proliferation, and the induction of tumor cell death. FGFRs are a family of receptor tyrosine kinases, which may be upregulated in various tumor cell types and may be involved in tumor cell differentiation and proliferation, tumor ang iogenesis, and tumor cell survival. 